\title{
PERBEDAAN MODALITAS VISUAL, AUDITORIAL DAN KINESTETIK SISWA KELAS X SMK JURUSAN TEKNIK PERMESINAN DAN TEKNIK KENDARAAN RINGAN
}

\author{
Margaretha F. Dian Pratiwi \\ Alumni Program Studi Bimbingan dan Konseling \\ FKIP- Universitas Kristen Satya Wacana \\ Sumardjono Padmomartono \\ Program Studi Bimbingan dan Konseling \\ FKIP - Universitas Kristen Satya Wacana
}

\begin{abstract}
ABSTRAK
Penelitian ini bertujuan untuk mengetahui signifikansi perbedaan modalitas siswa antar Jurusan Teknik Mesin dan Teknik Kendaraan Ringan kelas X SMK Muhammadiyah Salatiga. Subjek penelitian ini adalah seluruh siswa kelas X Jurusan Teknik Mesin dan seluruh siswa Teknik Kendaraan Ringan SMK Muhammadiyah Salatiga. Instrumen yang digunakan adalah kuesioner modalitas belajar. Adapun teknik analisis data menggunakan Chi Square yang diolah dengan program SPSS 16.0 for Windows. Analisis komparatif dengan menggunakan Chi-Square didapat value 9,384 dengan nilai signifikansi 0,009 $<0,01$. Dengan demikian, hasil analisis menunjukkan terdapat perbedaan yang sangat signifikan antara modalitas visual, auditorial, kinestetik siswa kelas X Teknik Permesinan dan Teknik Kendaraan Ringan di SMK Muhammadiyah Salatiga.
\end{abstract}

Kata Kunci: Modalitas Visual, Auditorial, Kinestetik, Siswa SMK Teknik Permesinan, Siswa SMK Teknik Kendaraan Ringan

\section{PENDAHULUAN}

\section{Latar Belakang Masalah}

Modalitas inderawi dalam belajar memiliki peranan penting dalam proses kegiatan pembelajaran. Sekolah Menengah Kejuruan/SMK Muhammadiyah Salatiga mempunyai berbagai penjurusan yaitu Teknik Permesinan, Teknik Instalasi Tenaga Listrik, Teknik Kendaraan Ringan dan Garmen. Siswa memilih sendiri jurusan yang diminati sejak awal kelas X. Berdasarkan pengamatan yang dilakukan penulis, siswa suka berjalan hilirmudik di dalam kelas, lebih santai, cenderung lebih ramai dan gaduh, suka bercanda, serta sedikit yang tertib dalam belajar di dalam kelas.
Berdasarkan wawancara dengan beberapa guru SMK Muhammadiyah diperoleh informasi bahwa siswa memakai berbagai modalitas atau gaya dalam belajar. Penulis memandang identifikasi modalitas inderawi siswa dalam belajar diharapkan dapat membantu sekolah dan guru dalam menentukan pola pembelajaran yang sesuai dengan modalitas siswa. Oleh karena itu perlu diinventarisasikan modalitas tiap siswa terutama siswa Jurusan Teknik Permesinan dan Teknik Kendaraan Ringan.

De Porter dan Hernacki (Ghufron, 2012) memaparkan bahwa ada tiga modalitas yaitu modalitas visual, auditorial dan kinestetik. Penelitian yang dilakukan Wijayanti (2013) tentang "Perbedaan antara 
Gaya Belajar Siswa Laki-Laki dan Perempuan dalam Belajar Matematika pada Siswa Kelas VIII SMP Kristen Satya Wacana Salatiga" menunjukkan terdapat perbedaan yang signifikan antara modalitas siswa lakilaki dan siswa perempuan dalam belajar matematika pada siswa kelas VIII SMP Kristen Satya Wacana Salatiga. Mursutami (2013) dalam penelitiannya menunjukkan tidak ada hubungan positif dan signifikan antara modalitas kinestetik dengan prestasi belajar matematika siswa kelas $\mathrm{X}$ jurusan Akuntansi SMK Diponegoro Salatiga.

Berdasarkan latar belakang, perlu diteliti signifikansi perbedaan modalitas visual, auditorial, dan kinestetik siswa antar Jurusan Teknik Permesinan dan Teknik Kendaraan Ringan siswa kelas X SMK Muhammadiyah Salatiga.

\section{Kajian Teori Gaya Belajar}

\section{Modalitas Inderawi dalam Belajar}

Proses belajar siswa dipengaruhi oleh modalitas yang lebih dikenal sebagai gaya dalam belajar. Gaya dalam belajar diartikan sebagai pola yang dipilih individu dalam memperoleh, menggunakan dan memikirkan tentang pengetahuan. Woolfolk dan Walkup (2008) mengartikan modalitas sebagai kecenderungan siswa memilih kondisi di mana, kapan, dengan siapa dan dengan apa, serta di dalam proses belajar yang mana kondisi pilihannya itu berdampak bagi belajar.

Susilo (2006) mengemukakan, modalitas juga didefinisikan sebagai caracara yang digunakan untuk mempermudah proses belajar. Siswa menggunakan caracara tertentu untuk membantunya mengerti materi pelajaran. Siswa dapat memperhatikan bagaimana modalitas tersebut didayagunakan supaya siswa lebih mudah mengerti materi pelajaran dan mengembangkan potensi belajar dengan optimal. Hal inilah yang menjadi landasan mengetahui pentingnya modalitas dalam belajar supaya siswa memahami materi pelajaran dengan cepat dan optimal.

Modalitas belajar memegang peran kunci dalam menentukan cara siswa mengamati dan menanggapi lingkungan belajar. Pemahaman guru tentang gaya siswa belajar membantu guru menetapkan pilihan pembelajaran yang berpeluang besar mengoptimalkan proses belajar siswa. Ada sejumlah bidang temuan yang berfaedah untuk mengoptimalisasikan belajar siswa, diantaranya cognitive styles, brain hemisphericity (dominasi dampak fungsi belahan otak pada belajar siswa) dan sensory modalities (modalitas inderawi dalam belajar) yang berkaitan dengan gaya dalam belajar.

Modalitas inderawi adalah sistem berinteraksi dengan lingkungan melalui satu atau lebih indera dasar, yaitu penglihatan, pendengaran, perabaan, pembauan, pengecapan. Modalitas yang diutamakan guru adalah visual/penglihatan, auditory/ pendengaran dan kinesthetic/gerak-halus psikomotorik. Informasi pembelajaran terutama diterima melalui indera itu. Informasi dapat terlupakan kemudian; setelah pemrosesan awal, informasi disimpan di ingatan jangka pendek atau jangka panjang.

Belajar dapat dikembangkan bila informasi diterima melalui modalitas inderawi pilihan siswa. Penggunaan pendekatan pembelajaran yang bervariasi memperbesar peluang siswa memproses isi pembelajaran secara lebih optimal melalui satu atau lebih indera dasarnya. Dengan demikian sejumlah siswa menggunakan pendekatan seperti: 1) Auditory, siswa lebih memilih belajar melalui mendengarkan dengan seksama bahan yang dipelajarinya. 2) Visual, siswa lebih memilih belajar me-lalui mengamati/melihat dengan 
seksama bahan yang dipelajari. 3) Kinesthetic, siswa lebih memilih belajar melalui melakukan tindakan tertentu atau turun tangan langsung menangani bahan yang dipelajari.

Dapatkah seseorang menggunakan lebih dari satu jenis modalitas belajar yang utama? Jawabannya yaitu ya! Sejumlah individu menggunakan dua modalitas belajar sebagai metode yang dipilihnya untuk belajar. Cara individu memproses informasi mempengaruhi gaya dalam belajarnya. Ada dua jalan individu memproses informasi, yaitu: 1) Proses analitis, individu menggunakan potongan-potongan kecil informasi untuk membangun gambaran yang lebih besar. 2) Proses relasional, individu mengamati bahan belajar sebagai sebuah gambaran yang besar kemudian memecahkannya ke dalam potongan-potongan informasi yang lebih kecil.

De Porter dan Hernacki (Ghufron, 2012) membagi gaya dalam belajar berdasarkan modalitas seseorang dalam memproses bahan belajar menjadi tiga kelompok, yaitu: modalitas belajar visual, modalitas belajar auditorial dan modalitas belajar kinestetik. Adapun karakteristik tiap modalitas belajar yaitu:

1) Modalitas Belajar Visual, yaitu belajar dengan cara melihat bahan belajar.

Modalitas belajar visual adalah cara menyerap informasi dengan mengutamakan kemampuan penglihatan. Individu dengan modalitas belajar visual lebih mengandalkan pengerahan indera penglihatan. Siswa bermodalitas belajar visual senang belajar melalui membaca (diam), mengamati dengan seksama orang yang sedang mengerjakan sesuatu serta lebih senang diberi contoh ketika belajar. Siswa berpikir dengan menggunakan gambar-gambar di dalam pikirannya dan belajar lebih cepat dengan menggunakan tampilan-tampilan visual, seperti diafragma, buku pelajaran bergambar, dan video.

2) Modalitas Belajar Auditorial, yaitu belajar dengan cara mendengar.

Modalitas belajar auditorial adalah kemampuan menyerap informasi atau pengetahuan dengan cara mendengarkan. Siswa yang terbiasa menggunakan modalitas belajar auditorial amat bertumpu pada indera pendengarannya ketika belajar. Siswa belajar secara auditory, yaitu belajar melalui pengerahan indera pendengaran. Siswa senang belajar melalui menyimak rekaman tape audio, mengikuti ceramah, debat, diskusi dan mencermati instruksi guru yang disampaikan secara lisan.

3) Modalitas Belajar Kinestetik, yaitu belajar dengan cara bergerak, bekerja dan menyentuh.

Modalitas belajar kinestetik adalah kemampuan menyerap informasi dengan cara bergerak, bekerja dan menyentuh. Siswa bermodalitas belajar kinestetik ini menggunakan indera peraba, dengan merasakan sesuatu menggunakan indera peraba (tangan). Siswa dengan tipe ini aktif mengerjakan sesuatu agar dapat mengerti daripada sekedar duduk diam membaca atau duduk diam mendengarkan guru mengajar. Siswa yang belajar secara kinesthetic sangat bertumpu pada pengerahan kegiatan fisik dan melibatkan diri secara langsung pada kegiatan belajar. Siswa suka belajar melalui mempraktikkan langsung, bergerak kiankemari, menyentuh bahan, mengalami sendiri pengalaman bersentuhan langsung dengan kegiatan belajar.

Jurusan Teknik Permesinan dan Teknik Kendaraan Ringan di SMK Jurusan Teknik Permesinan di SMK menekuni ilmu terapan energi dan sumber energinya. Halhal yang dipelajari dalam teknik mesin 
banyak berurusan dengan mesin penggerak awal, seperti turbin uap, motor bakar, mesinmesin perkakas, pompa dan kompresor, pendingin dan pemanas, dan alat-alat kimia tertentu. Dalam mesin penggerak awal, teknik mesin mengajarkan cara penggunaan mesin yang efisien dan ekonomis.

Hal lain yang dipelajari dalam Teknik Permesinan adalah sifat fisis dan fenomena yang terjadi pada suatu bahan. Hal ini termasuk sifat bahan dalam menyangga tarikan, tekanan, momen, atau puntiran. Sifat bahan penting untuk dipelajari dikarenakan dalam mendesain suatu barang, siswa harus menentukan dulu kegunaan barang tersebut dan gaya-gaya apa saja yang akan diperlakukan pada barang tersebut. Dalam teknik mesin juga diajarkan untuk mengubah sifat suatu bahan jika didapat tidak ada bahan yang memenuhi persyaratan, yaitu dengan perlakuan panas ataupun penambangan unsur-unsur tertentu di dalam bahan yang tersedia di alam.

Banyak orang berpendapat bahwa seseorang yang masuk penjurusan di Teknik Permesinan akan mendapatkan ilmu tentang mesin-mesin otomotif. Hal ini tidak salah, tetapi kurang tepat. Karena untuk dapat memiliki kemampuan memperbaiki mesinmesin otomotif, tidak cukup siswa masuk ke jurusan otomotif. Bahkan, jika seseorang mengambil jurusan otomotif, maka orang tersebut sudah memiliki kemampuan yang cukup dalam memperbaiki mesin-mesin otomotif. Jadi, Teknik Permesinan mengajarkan lebih dari itu.

Di lain pihak, Teknik Kendaraan Ringan (TKR) merupakan kompetensi keahlian bidang teknik otomotif yang menekankan keahlian pada penguasaan jasa perbaikan kendaraan ringan. Kompetensi keahlian teknik kendaraan ringan menyiapkan siswa untuk bekerja pada bidang pekerjaan jasa perawatan dan perbaikan di dunia usaha/industri. Secara khusus tujuan Kompetensi Keahlian Teknik Kendaraan Ringan adalah membekali siswa dengan keterampilan, pengetahuan dan sikap agar kompeten memahami dasar-dasar mesin, siswa memahami proses-proses dasar pembentukan logam, siswa dapat menjelaskan prosesproses mesin konversi energi, menginterpretasikan gambar teknik, menggunakan peralatan dan perlengkapan di tempat kerja, menggunakan alat-alat ukur, menerapkan prosedur keselamatan, kesehatan kerja dan lingkungan tempat kerja, memperbaiki sistem hidrolik dan kompresor udara. Siswa juga dapat melaksanakan prosedur pengelas an, pematrian, pemotongan dengan panas dan pemanasan, memelihara/servis sistem bahan bakar bensin, memperbaiki unit kopling dan komponen-komponen sistem pengoperasian, Teknik Kendaraan Ringan dapat memperbaiki poros penggerak roda dan ban, memperbaiki sistem rem, sistem kemudi, sistem suspensi, kerusakan ringan pada rangkaian/sistem kelistrikan, pengaman dan kelengkapan tambahan, memperbaiki sistem pengapian, sistim starter dan pengisian, memelihara/servis sistem AC (Air Conditioner).

\section{METODE PENELITIAN}

Jenis penelitian yang digunakan adalah penelitian komparatif. Subyek penelitian ini adalah semua siswa kelas $\mathrm{X}$ jurusan Teknik Permesinan yang berjumlah 71 siswa dan Teknik Kendaraan Ringan SMK Muhammadiyah Salatiga yang berjumlah 95 siswa. Seluruh siswa kelas $\mathrm{X}$ jurusan Teknik Permesinan yang berjumlah 71 siswa dan Teknik Kendaraan Ringan SMK Muhammadiyah Salatiga yang berjumlah 95 siswa itu ditetapkan sebagai sampel total. Teknik analisis data yang digunakan dalam penelitian ini adalah $C h i$ 
Square yang diolah dengan bantuan program SPSS for Windows (Santoso, 2008).

Berdasarkan hasil penelitian, dari 71 siswa kelas Teknik Permesinan, 25 siswa $(35,2 \%)$ bermodalitas visual, 20 siswa $(28,2 \%)$ bermodalitas auditorial serta 26 $(36,6 \%)$ bermodalitas kinestetik. Disimpulkan sebagian besar siswa Teknik Permesinan bermodalitas kinestetik $(36,6 \%)$ dan bermodalitas visual $(35,2 \%)$.

Di lain pihak, pada siswa Teknik Kendaraan Ringan, dari 95 siswa diperoleh gambaran 16 siswa $(16,8 \%)$ bermodalitas visual, 45 siswa $(47,4 \%)$ bermodalitas auditorial serta 34 siswa $(35,8 \%)$ bermodalitas kinestetik. Berarti sebagian besar siswa Teknik Kendaraan Ringan bermodalitas auditorial $(47,4 \%)$ dan bermodalitas kinestetik (35,8\%).

Selanjutnya dirangkum olahan Pearson Chi-Square pada Tabel 2.

Dari Tabel 2. didapat hasil uji Pearson Chi-Square 9,384 dengan nilai signifikansi 0,009 . Dengan melihat nilai signifikansi sebesar 0,01 (1\%) ternyata lebih kecil dari taraf signifikansi yaitu 0,009 $<0,01$. Diambil kesimpulan ada perbedaan yang sangat signifikan pada modalitas visual, auditorial, dan kinestetik siswa kelas X Teknik Permesinan dan Teknik Kendaraan Ringan SMK Muhammadiyah Salatiga.

Hasil uji analisis data menunjukkan bahwa terdapat perbedaan yang sangat signifikan antara modalitas visual, auditorial dan kinestetik siswa kelas X Teknik Permesinan dengan siswa kelas X Teknik Kendaraan Ringan. Penelitian ini menunjukkan signifikansi perbedaan modalitas siswa kelas $\mathrm{X}$ Teknik Permesinan dan Teknik Kendaraan Ringan di SMK Muhammadiyah Salatiga.

Sebagian besar siswa kelas X Jurusan Teknik Permesinan lebih mudah belajar dengan modalitas kinestetik, siswa lebih mengerti informasi bila dapat merasakan sesuatu dengan menggunakan indera peraba (tangan) dan aktif mengerjakan sesuatu.

Tabel 1 Modalitas Visual, Auditorial, dan Kinestetik Siswa Kelas X Teknik Permesinan dan Teknik Kendaraan Ringan

\begin{tabular}{|c|c|c|c|c|c|c|}
\hline & & & \multicolumn{3}{|c|}{ GayaBelajar } & \multirow[b]{2}{*}{ Total } \\
\hline & & & Visual & Audio & Kinestetik & \\
\hline \multirow{4}{*}{ Kelas } & \multirow{2}{*}{ Teknik Permesinan } & Count & 25 & 20 & 26 & 71 \\
\hline & & $\%$ within kelas & $35.2 \%$ & $28.2 \%$ & $36.6 \%$ & $100.0 \%$ \\
\hline & \multirow{2}{*}{ Teknik Kendaraan Ringan } & Count & 16 & 45 & 34 & 95 \\
\hline & & $\%$ within kelas & $16.8 \%$ & $47.4 \%$ & $35.8 \%$ & $100.0 \%$ \\
\hline \multirow[t]{2}{*}{ Total } & & Count & 41 & 65 & 60 & 166 \\
\hline & & $\%$ within kelas & $24.7 \%$ & $39.2 \%$ & $36.1 \%$ & $100.0 \%$ \\
\hline
\end{tabular}

Tabel 2 Uji Beda Modalitas Visual, Auditorial, dan Kinestetik Siswa Kelas X Teknik Permesinan dan Teknik Kendaraan Ringan

\begin{tabular}{lccc}
\hline \multicolumn{4}{c}{ Chi-Square Tests } \\
\hline & Value & Df & Asymp. Sig. (2-sided) \\
\hline Pearson Chi-Square & $9.384^{\mathrm{a}}$ & 2 & .009 \\
Likelihood Ratio & 9.447 & 2 & .009 \\
Linear-by-Linear Association & 2.087 & 1 & .149 \\
N of Valid Cases & 166 & & \\
\hline a. O cells (,0\%) have expected count less than 5. The minimum expected count is 17,54.
\end{tabular}


Siswa lebih aktif mengerjakan sesuatu agar dapat mengerti bahan belajar daripada sekedar duduk diam membaca atau mendengarkan guru mengajar. Selanjutnya sebagian lebih kecil jumlah siswa, leluasa belajar dengan modalitas visual, yaitu menyerap informasi dengan mengutamakan kemampuan penglihatan, mengandalkan pengerahan indera penglihatan yang terekspresikan melalui membaca (diam), mengamati seksama orang yang sedang mengerjakan sesuatu serta senang diberi contoh ketika belajar. Siswa berpikir menggunakan gambar di dalam pikirannya dan belajar lebih cepat dengan menggunakan tampilan visual, seperti diafragma, buku pelajaran bergambar dan video.

Di lain pihak, siswa kelas X Jurusan Teknik Kendaraan Ringan cenderung dominan pada modalitas auditorial, yaitu kemampuan menyerap informasi atau pengetahuan dengan cara mendengarkan. Siswa yang menggunakan modalitas auditorial amat bertumpu pada indera pendengarannya ketika belajar. Siswa senang belajar melalui menyimak rekaman tape audio, mengikuti ceramah, debat, diskusi dan mencermati instruksi guru yang disampaikan secara lisan. Siswa cepat belajar melalui menggunakan diskusi verbal dan mendengarkan apa yang dikemukakan guru.

Temuan penelitian ini ternyata sejalan dengan penelitian yang dilakukan oleh Wijayanti (2013) yang menunjukkan ada perbedaan yang signifikan pada modalitas siswa laki-laki dan pada modalitas siswa perempuan. Sebagian besar (49\%) siswa laki-laki kelas VIII SMP Kristen Satya Wacana bermodalitas visual dalam belajar matematika, sedangkan sebagian lebih kecil (44\%) bermodalitas auditorial.

\section{SIMPULAN}

Berdasarkan analisis dan pembahasan, dapat disimpulkan terdapat perbedaan yang sangat signifikan antara modalitas visual, auditorial dan kinestetik siswa kelas X Teknik Permesinan dengan siswa kelas X Teknik Kendaraan Ringan di SMK Muhammadiyah Salatiga. Sebagian besar siswa kelas $\mathrm{X}$ Jurusan Teknik Permesinan lebih mudah belajar dengan modalitas kinestetik, siswa lebih mengerti informasi bila dapat merasakan sesuatu dengan menggunakan indera peraba (tangan) dan aktif mengerjakan sesuatu. Selanjutnya sebagian lebih sedikit siswa, leluasa belajar dengan modalitas visual, yaitu menyerap informasi dengan mengutamakan kemampuan penglihatan, lebih mengandalkan pengerahan indera penglihatannya yang terekspresikan melalui membaca (diam), mengamati dengan seksama orang yang sedang mengerjakan sesuatu serta lebih senang diberi contoh ketika belajar.

Di lain pihak, siswa kelas X Jurusan Teknik Kendaraan Ringan dominan pada modalitas auditorial, yaitu kemampuan menyerap informasi atau pengetahuan dengan cara mendengarkan. Siswa senang belajar melalui menyimak rekaman tape audio, mengikuti ceramah, debat, diskusi dan mencermati instruksi guru yang disampaikan secara lisan. Ada sebagian lebih sedikit siswa belajar dengan modalitas kinestetik, siswa lebih mengerti informasi bila dapat merasakan sesuatu dengan indera peraba (tangan) dan aktif mengerjakan sesuatu.

\section{REKOMENDASI}

Berdasarkan simpulan penelitian, direkomendasikan bagi guru Jurusan Teknik Permesinan untuk menerapkan strategi pembelajaran yang mendorong siswa mengerahkan modalitas auditorial dalam belajar; 
bagi guru Jurusan Teknik Kendaraan Ringan perlu memakai strategi pembelajaran yang memancing siswa berlatih menggunakan modalitas visual, kemudian modalitas kinestetik. Melalui strategi pembelajaran untuk mendorong siswa mendayagunakan ketiga jenis modalitas visual, auditorial dan kinestetik secara seimbang, diharapkan proses belajar siswa lebih optimal.

Selanjutnya direkomendasikan pada siswa kedua jurusan agar berupaya berlatih mengerahkan secara serempak ketiga jenis modalitas visual, auditorial dan kinestetik agar proses belajarnya lebih optimal sehingga penguasaan kompetensi teknikal makin meningkat. Sedangkan bagi penelitian lanjutan, disarankan untuk melakukan eksperimen penerapan strategi pembelajaran yang memadukan ketiga jenis modalitas visual, auditorial dan kinestetik pada siswa SMK Jurusan Teknik Permesinan maupun siswa SMK Jurusan Teknik Kendaraan Ringan.

\section{DAFTAR PUSTAKA}

Ghufron, Nur M. 2012. Gaya Belajar: Kajian Teoretik. Yogyakarta: Pustaka Pelajar.

Mursutami. 2013. Hubungan antara Gaya Belajar Kinestetik dengan Prestasi Belajar Matematika Siswa Kelas X Akuntansi SMK Diponegoro Salatiga. Skripsi. Program Studi Pendidikan Matematika, FKIP - Universitas Kristen Satya Wacana Salatiga.

Santoso, Singgih. 2008. Panduan Lengkap Menguasai SPSS 16. Jakarta: Elex Media Komputindo.

Susilo, J. 2006. Gaya Belajar Menjadi Makin Pintar. Yogyakarta:Pinus Book Publisher.

Wijayanti, Okta I. 2013. Perbedaan antara Gaya Belajar Siswa Laki-laki dan Perempuan dalam Belajar Matematika pada Siswa Kelas VIII SMP Kristen Satya Wacana Salatiga. Skripsi. Program Studi Pendidikan Matematika, FKIP-Universitas Kristen Satya Wacana Salatiga.

Woolfolk, A., M. Hughes, and V. Walkup. 2008. Psychology in Education. London: Pearson Longman. 